centres are well equipped and staffed, and have met with undoubted success since their inception in 1960.

Mr Sneed says that the scale of Japanese education should not be underestimated. In 1966 there were 346 four-year universities, of which 111 were operated by the state. More than 70 per cent of Japanese children stay on at school until or past the age of 18 , and 11 per cent receive a university education. In England, 7.3 per cent of boys and 3.2 per cent of girls go to university; these figures, however, are not of course strictly comparable.

In the United States Mr Sneed says he has investigated the Engineering Concepts Curriculum Project (ECCP), a scheme which calls for the development of an introductory course in engineering and the training of teachers to conduct it. The aim is not specifically to attract students to a career in engineering but, like the industrial arts course in Japan, to provide an understanding of the technical background of modern life. There are signs that the popularity of engineering as a career in the United States is decreasing and, although it is too early yet to evaluate the course developed by the ECCP, its progress will be watched with interest.

\section{Education for Engineers}

Plans to bring the United States Commission on Engineering Education into the structure of the National Academy of Engineering were announced in Washington DC last week. The commission was founded by the National Science Foundation in 1962 to meet the needs for improving undergraduate education in engineering. It is supported by the NSF and by private means. Since 1962, the work has covered areas such as the educational aspects of computers, manpower requirements for engineers in specifie fields, the development of an Engineering Concepts Curriculum Project for high schools and the development of undergraduate engineering laboratories.

The reason for the proposed association is that the commission recognized a need to establish "a more substantial basis of operation than that provided by its independent status". According to Dr Eric A. Walker, president of the National Academy of Engineering, it is hoped that this relationship will encourage new ideas and new programmes as well as establishing co-operation with other organizations dealing with engineering education. Formal dissolution of the commission as a corporation will take place no later than March 1, 1969. Meanwhile, the commission will continue to administer existing programmes, and new projects will be handled by the Committee on Engineering Education within the academy.

\section{Some Steam Ahead}

THe award to a British company of a contract for a large turbine generator for Consolidated Edison in New York is a considerable coup at any time. To beat General Electric and Westinghouse, and the highly effective Swiss company Brown Boveri, adds savour to the triumph. But there must be some long faces in Associated Electrical Industries just the same. If the order had come only two months ago, it might have been decisive in turning away the bid with which
Mr Arnold Weinstock of the General Electric Company took over AEI. Naturally AEI is trying very hard to play down the issue, despite its jubilation at winning the order. Mr Weinstock, for his part, must be gratified that the turbine division of his new empire is already giving evidence of its competitiveness-it could mean one less problem for him, and keep alive hopes of maintaining the division through a difficult period. The Central Electricity Generating Board is now cutting back so hard on new orders-despite the recent cold spell, it still had substantial spare capacity- that there is little hope of selling generating capacity in Britain for the next two years or so. Export orders are therefore more than just an encouragement-they are a lifesaver.

The contract which AEI has won is for one turbine generator with auxiliary equipment, worth $£ 10$ million; but it is more than likely that an order for another similar unit will be forthcoming. Placing contracts in this way is a common practice in the United States, and AEI is confident of winning the option. The generator is of unprecedented size for a British company-1,100 MW from a single shaft, against the 660 MW units which the CEGB has reached. The unit will be run from a boiling light water reactor, and will be a relatively low pressure, low temperature unit, running at $1,800 \mathrm{rpm}$. These units are different from the ones the CEGB uses, which use a higher grade steam.

Because the steam from the reactor will be saturated with water, and partially decomposed into hydrogen and oxygen, there are particular corrosion and erosion problems on the turbine blades. The amount of erosion depends on the tip speed of the turbine blades, so it pays to keep this as low as possible. AEI has managed to do this by using a device developed by one of its engineers-the Baumann multi-exhaust. Although the other tenders for the Con Ed contract specified a blade size of 52 inches for the final set of blades, AEI says that its blades are much smaller. The generator will use a combination of cooling techniques. The stator will be water cooled, by a design which AEI itself developed. But, although there had been speculation that the rotor would also have to be water cooled on a unit this size, AEI have provided hydrogen cooling. This is not because it is technically impossible to cool the rotor with waterAEI is convinced that it knows how to do it-but merely because it might provide a weak link in the design. Cooling by hydrogen gas is well proved, so AEI has decided to use it.

The set will also be provided with a series of water separators, designed to remove as much water as possible from the steam. In the design of these, AEI will be calling on the experience gained in the contract for the turbines for the steam generating heavy water reactor at Winfrith Heath in Dorset. Although the SGHWR is very much smaller than the Con Ed contract, it shares some of the problems.

\section{The Lunar Society}

$$
\text { from D. G. Kin o-Hele }
$$

THE informal but influential meetings of the Lunar Society of Birmingham began about the year 1766, and its 200th anniversary was commemorated in 
October 1966 (see Nature, 212, 229; 1966). At Birmingham the bicentenary was cclcbrated with a finc exhibition at the City Museum and Art Gallery, seen by 90,000 people, and with a series of lectures, which has now been published in the University of Birmingham Historical Journal (Vol. XI, No. 1, pp. 1-111; 1967). The texts of the seven lectures are prefaced by the address at the opening of the exhibition, given by the President of the Royal Socicty. Professor Blackett stresses the important role of the Lunar Society in helping to bring about the Industrial Revolution, particularly through the work of Boulton, Watt, Keir and Wedgwood. He also draws attention to the "allimportance of the marriage between science, technology and industrial management", so well exemplified by the members of the Lunar Society, and subsequently so sadly neglected in Britain until very recently.

The first of the lectures, on "The Origins and Lifespan of the Lunar Society", was given by Eric Robinson, who also wrote the greater part of the excellent catalogue of the exhibition. The Lunar Society originated in the meetings of Erasmus Darwin, William Small and Matthew Boulton which, Mr Robinson concludes, were certainly taking place by 1766, often in Darwin's house at Lichfield. The end of the society, like its beginning, was ill-defined: $M r$ Robinson shows that it survived until about 1807 .

The next two contributions are devoted to individual members of the society. Lord Cohen of Birkenhead gives an interesting account of the life and work of Erasmus Darwin, well illustrated and with a useful bibliography of Darwin's published works. This is followed by an appreciation of William Withering by Sir John McMichael, who shows that Withering's use of digitalis in the treatment of dropsy was subtle and far-sighted. The next three lecturers discuss the influence of the Lunar Society on the development of chemistry, education and Birmingham. Chemistry brings in Priestley, Keir, Watt and Wedgwood in education the chief contributors were Edgeworth and Darwin; and in Birmingham it is Boulton who reigns supreme. In the final lecture, "The Lunar Society and the Industrial Revolution", R. E. Schofield skilfully sums up the contributions of the Lunar Society members in each branch of "industry", including medicine and agriculture, as well as technology in the narrow sense.

\section{More Trade}

DurINg this week, Academician V. A. Kirillin, chairman of the State Committee for Science and Technology of the USSR, has been visiting Britain. The principal reason for his visit is to sign the technological agreement between the UK and the USSR, which has been negotiated over recent months (see Nature, 216, 1060; 1967). From the British side the agreement will be signed by $\mathrm{Mr}$ Anthony Wedgwood Benn, Minister of Technology, and Mr Frederick Mulley, Minister of State at the Foreign Office.

Meanwhile, the day before Mr Kirillin's arrival, another agreement between the UK and the USSR was bcing signed. It is called the Anglo-Soviet trade agreement, and covers the import and export of consumer goods. The agreement has been in force since 1959 , and the most recent signing takes it forward to
December 31, 1968. The agreement sets up quotas for the trade of consumer goods-the quotas now stand at $\$ 7.4$ million for the import of Russian goods into the UK, and $£ 6.7$ million for the export of UK goods to the USSR. These figures, the Board of Trade says, are 60 per cent larger than those agreed for the previous year. They are still remarkably small, but fortunately do not represent the full amount of UK-USSR tradc. Although all trade is carried on within the agreement, the Board of Trade explains that over 90 per cent of it takes place outside the quotas.

The USSR seems to be gelling slightly the better of the balance of trade at the moment. During 1966, UK imports from the USSR amounted to $£ 125.6$ million, while exports were just over $\mathfrak{f 5 0}$ million. Up to the end of November 1967, the balance was slightly more favourable. In the 11 months, UK exports to the USSR were $£ 61 \cdot 7$ million, while imports were down to $£ 107 \cdot 6$ million.

The new quotas agreed should offer instrument manufacturers a new chance. The USSR authorities have agreed to import from Britain scientific instruments to the value of $£ 1 \cdot 1$ million. They are also prepared to import $£ 1.08$ million worth of chemicals and $\$ 820,000$ worth of man-made yarns and fibres. But it is clear that the vast majority of UK-USSR trade will continue to take place outside the quotas.

\section{Cost of Accidents}

AT a measurable cost to Britain of $£ 246$ million for 1965 alone, road accidents are expensive. $\mathrm{Mr} \mathrm{R}$. F. F. Dawson, of the Road Research Laboratory, has been making detailed investigations into the costs and has now produced figures which he believes to bc more accurate than previous estimates made in 1938 and 1952. For the first time a value has been placed on human life and the prevention of suffering, and these subjective costs have been added to the measurable costs to give a figure which represents the total cost of accidents. The figure of $f 1,020$ is put forward by $\mathrm{Mr}$ Dawson, for use in economic calculations, as the average cost per accident for all areas. This and other conclusions can be found in a report, The Cost of Road Accidents in Great Britain, which was published last week (RRL Report L.R.79).

Costs of accidents are considered to arise from three sources: injury to people, damage to property and from incidental expenses such as police and insurance administration. Costs of insurance premiums are not included as these would not decrease even if the number of accidents was reduced. Damage to property and incidental expenses are paid for by a diversion of current resources, and are comparatively easy to measure. Insurance payments during 1963 put the cost of damage to vehicles and other property at $£ 128$ million. Fstimates of police man-hours spent in coping with accidents were made and the cost to the police for 1963 came out at $£ 4$ million. Insurance administration costs were set at $£ 20$ million. Injuries to peoplc are the most difficult factor to evaluate. Current costs of medical treatment and long term effects of loss of output can be estimated with a fair degree of certainty, but the additional cost to individuals of serious injury or fatal accidents is a matter for specu-

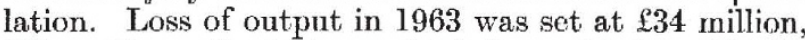
$£ 20$ million of which resulted from fatal accidents. 